\section{INACTIVATION OF $\beta$-LACTAMASE BY SOME SITE-SPECIFIC REAGENTS}

Sir:

In relation to the screening program of inhibitors $^{1)}$ of $\beta$-lactamases, we isolated a new type of $\beta$-lactamase from Escherichia coli carrying an R factor derived from a Proteus strain ${ }^{2}$. This enzyme is sensitive to $p$-chloromercuribenzoate and inhibited by cloxacillin. In order to explore the chemical nature of its active site, we studied the inactivation of this enzyme $\left(\beta\right.$-lactamase $\left.{ }_{75}\right)$ by some site-specific reagents, comparing the results with those obtained with a Bacillus cereus penicillinase obtained from the CalbioChem. $\beta$-Lactamase ${ }_{75}$ (approximately $\left.1.5 \times 10^{-7} \mathrm{M}\right)$ was incubated with specific penicillin isocyanates at the concentration indicated in Table 1 in $0.1 \mathrm{~m}$ sodium phosphate buffer containing $1 \mathrm{~mm}$ dithiothreitol, $\mathrm{pH} 7.4$ or 5.9 at $30^{\circ} \mathrm{C}$ for 15 or 30 minutes. The isocyanate was added in $5 \mu \mathrm{l}$ of acetone solution. In the control, $5 \mu 1$ of acetone was added to the incubation mixture instead of the isocyanate solution. The preparation of the penicillin isocyanates used in this paper and the method of measurement of the enzymatic activity were described in a previous paper $^{3)}$. Results in Table 1 show that both the isocyanate group and the $\beta$-lactam ring are involved in reduction or inactivation of the enzymatic activity. The former is necessary for the chemical reactivity of the reagent

Table 1. Effect of various isocyanates on the activity of $\beta$-lactamase ${ }_{75}$

\begin{tabular}{|c|c|c|c|c|}
\hline Reagents & $\begin{array}{c}\text { Concen- } \\
\text { tration } \\
(\mu \mathrm{M})\end{array}$ & $\mathrm{pH}$ & $\begin{array}{c}\text { Time } \\
\text { of } \\
\text { reaction } \\
\text { (min.) }\end{array}$ & $\begin{array}{l}\text { Activity } \\
\text { re- } \\
\text { maining } \\
(\%)\end{array}$ \\
\hline BPI & $\begin{array}{l}20 \\
10\end{array}$ & $\begin{array}{l}7.4 \\
5.9\end{array}$ & $\begin{array}{l}15 \\
30\end{array}$ & $\begin{array}{l}56 * \\
47 *\end{array}$ \\
\hline PPI & $\begin{array}{l}20 \\
10\end{array}$ & $\begin{array}{l}7.4 \\
5.9\end{array}$ & $\begin{array}{l}15 \\
30\end{array}$ & $\begin{array}{l}55^{*} \\
74^{*}\end{array}$ \\
\hline CPI & $\begin{array}{l}20 \\
10\end{array}$ & $\begin{array}{l}7.4 \\
5.9\end{array}$ & $\begin{array}{l}15 \\
30\end{array}$ & $\begin{array}{r}45 \\
9.5\end{array}$ \\
\hline$n$-Butylisocyanate & $\begin{array}{r}200 \\
10\end{array}$ & $\begin{array}{l}7.4 \\
5.9\end{array}$ & $\begin{array}{l}15 \\
30\end{array}$ & $\begin{array}{l}92 * \\
81 *\end{array}$ \\
\hline Phenylisocyanate & 100 & 7.4 & 15 & $87 *$ \\
\hline Control & & $\begin{array}{l}7.4 \\
5.9\end{array}$ & $\begin{array}{l}15 \\
30\end{array}$ & $\begin{array}{l}93 * \\
89 *\end{array}$ \\
\hline
\end{tabular}

* Cited as references from the data of reference 3$)$. to the enzyme, the latter is needed for the specific affinity of the reagent to the active site of the enzyme. Among penicillin isocyanates, carbenicillin isocyanate (CPI) shows the strongest action in reducing the activity of $\beta$-lactamase ${ }_{75}$, especially when reacted in an acidic region. Benzylpenicillin isocyanate (BPI) and 6-phthalimidopenicillanic acid isocyanate (PPI) had a similar strength in reducing the enzymatic activity. This suggests that interaction of the carboxyl group of CPI with a charged group in the enzyme enhances the binding of the reagent to the enzyme.

Incubation of $\beta$-lactamase ${ }_{75}$ with various concentrations of CPI produced a rapid inactivation of the enzyme (Fig. 1). The inactivation followed pseudo-first-order kinetics and the intercept on the $y$ axis was not zero. This fact shows that the inactivation is preceded by the formation of a reversible enzyme-reagent complex as in the case of $\mathrm{BPI}^{3)}$. If the inactivation is due to a chemical reaction on a group in the active site of the enzyme, the inactivation rate should be reduced in the presence of a competitive inhibitor to an extent depending on the affinity of a competitive inhibitor for the enzyme. In fact, methicillin, but not an alkaline degradation product of methicillin, reduced the inactivation rate by CPI and PPI (Table 2 and Table 3). This fact indicates that the inactivation proceeds through a chemical reaction of the reagents with a group in the active site of the enzyme.

The effect of $\mathrm{pH}$ on the inactivation rate by BPI and CPI was studied. $\beta$-Lactamase L $_{75}$ (approximately $1.5 \times 10^{-7} \mathrm{M}$ ) was incubated with BPI $\left(1 \times 10^{-5} \mathrm{M}\right)$ for 30 minutes in phos-

Fig. 1. Dependence of pseudo-first-order rate constant of inactivation on the concentration of CPI.

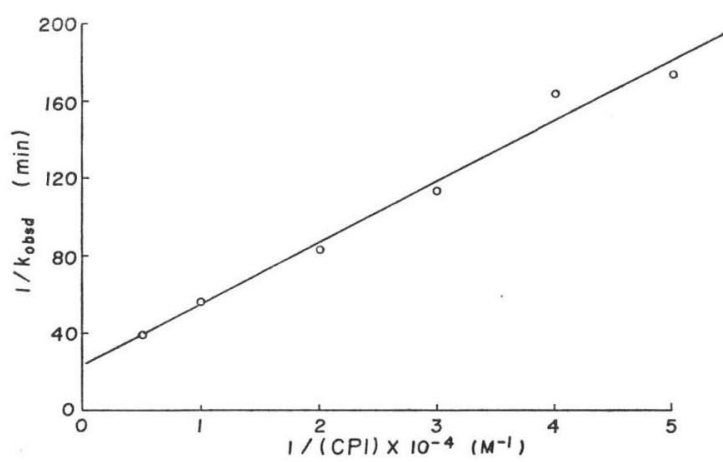


Table 2. Effect of methicillin and its degradation product on the inactivation of $\beta$-lactamase I $_{75}$ by CPI

\begin{tabular}{l|c|c}
\hline \multicolumn{1}{c|}{ Reagents } & $\begin{array}{c}\text { Concen- } \\
\text { tration } \\
(\mathrm{M})\end{array}$ & $\begin{array}{c}\text { Activity } \\
\text { remaining } \\
(\%)\end{array}$ \\
\hline $\mathrm{CPI}$ & $\begin{array}{c}1 \times 10^{-4} \\
1 \times 10^{-4}\end{array}$ & 11.8 \\
$\mathrm{CPI}$ & 63.2 \\
$\begin{array}{l}\text { Methicillin } \\
\text { CPI }\end{array}$ & $1 \times 10^{-3}$ & $60^{-4}$ \\
$\begin{array}{l}\text { Methicillin degrada- } \\
\text { tion product }\end{array}$ & 15.2 \\
\hline Control & & 84.0 \\
\hline
\end{tabular}

phate buffers. $\beta$-Lactamase La $_{75}$ (approximately $\left.7.5 \times 10^{-7} \mathrm{M}\right)$ was incubated with CPI $\left(2 \times 10^{-4} \mathrm{M}\right)$ for 1 hour in phosphate buffers of various $\mathrm{pH}$. In the case of CalbioChem penicillinase, the enzyme (approximately $2 \times 10^{-7} \mathrm{M}$ ) was incubated with CPI $\left(2 \times 10^{-4} \mathrm{M}\right)$ for 1 hour. From the results shown in Fig. 2, it is clear that both BPI and CPI inactivate the enzymatic activity of $\beta$-lactamase - $_{75}$ more strongly in an acidic condition than in a neutral or an alkaline condition, and the $\mathrm{pK}$ value which can be estimated from the data in Fig. 2 is about $6 \sim 6.5$. This is also the case with a penicillinase of $B$. cereus and CPI and $\beta$-lactamase f $_{75}$ and PPI (data not shown). Although this $\mathrm{pK}$ value may be due either to the dissociation of the isocyanate group of the reagents or to the one of the reactive group in the enzyme, it is more reasonable to consider that the latter should be the case, because the isocyanate group may not dissociate or associate with a proton only in this $\mathrm{pH}$ region. Considering these facts, the reactive group with a $\mathrm{pK}$ value of $6 \sim 6.5$, probably a histidyl residue in its protonated form of the enzyme, is involved in the inactivation reaction. The data in Fig. 2 also suggest that the amino acid arrangement is similar in the substrate binding sites of $\beta$-lactamase ${ }_{75}$ and a penicillinase of $B$. cereus. It has been reported ${ }^{4,5)}$ that reaction products of imidazoles with isocyanates dissociate readily to their components and react with amines to form substituted ureas. The fact that neither dialysis nor incubation with $1 \mathrm{M}$ hydroxylamine at $\mathrm{pH} 7.0$ reactivated the inactivated enzyme described above suggests that at first the isocyanates react with a histidyl residue and then proceed to react with a neighboring group,
Table 3. Effect of methicillin and its degradation product on the inactivation of $\beta$-lactamase ${ }_{75}$ by PPI

\begin{tabular}{l|c|c}
\hline \multicolumn{1}{c|}{ Reagents } & $\begin{array}{c}\text { Concen- } \\
\text { tration } \\
(\mathrm{M})\end{array}$ & $\begin{array}{c}\text { Activity } \\
\text { remaining } \\
(\%)\end{array}$ \\
\hline PPI & $\begin{array}{c}1 \times 10^{-4} \\
1 \times 10^{-4}\end{array}$ & 15.9 \\
$\begin{array}{l}1 \times 10^{-3} \\
\text { PPI }\end{array}$ & 54.7 \\
$\begin{array}{l}1 \times 10^{-4} \\
1 \times 10^{-3}\end{array}$ & 12.1 \\
$\begin{array}{l}\text { Pethicillin } \\
\text { Methicillin degrada- }\end{array}$ & & 75.4 \\
\hline Control & & \\
\hline
\end{tabular}

Fig. 2. Effect of $\mathrm{pH}$ on the inactivation of $\beta$ lactamases by BPI and CPI.

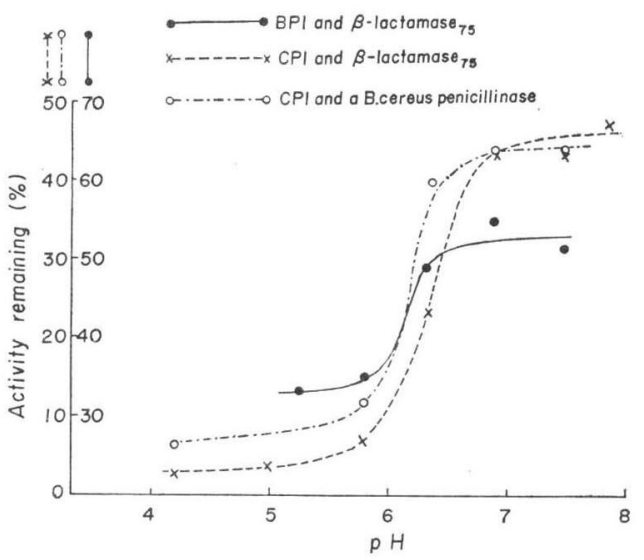

probably an amino group forming a stable inactivated enzyme. The first reaction is the rate-limiting step.

Preliminary experiments using oxacillin and methicillin derivatives with a varied length of "methylene arm" attached to the carboxyl group and reactive group in the terminal region of the arm (compounds with substitution at 3 position of the penicillin nucleus such as $-\mathrm{CO}-\mathrm{NH}-\mathrm{CH}-\left(\mathrm{CH}_{2}\right)_{\mathrm{n}}-\mathrm{NH}-\mathrm{COCH}_{2} \mathrm{Br}$, $\mathrm{COOH}$

$n=1,2,3$ and 4), showed that they did not inactivate $\beta$-lactamase ${ }_{75}$.

Hiroshi Ogawara HaMaO UMEZAWA

Department of Antibiotics, National Institute of Health, Kamiosaki-2-chome, Shinagawa-ku, Tokyo 141, Japan

(Received April 8, 1974) 


\section{References}

1) Umezawa, H.; S. Mitsuhashi, M. Hamada, S. Iyobe, S. Takahashi, R. Utahara, Y. Osato, S. Yamazaki, H. Ogawara \& K. MAEDA: Two $\beta$-lactamase inhibitors produced by a Streptomyces. J. Antibiotics 26: $51 \sim 54$, 1973

2) Ogawara, H.; K. Maeda \& H. Umezawa: A $\beta$-lactamase of Escherichia coli. Biochim. Biophys. Acta 289: 203 211, 1972
3) Ogawara, H. \& H. Umezawa: Affinity labeling of an Escherichia coli $\beta$-lactamase. Biochim. Biophys. Acta 327: 481 489, 1973

4) Stark, G.R.: Reactions of cyanate with functional groups of proteins. II. Formation, decomposition, and properties of N-carbamylimidazole. Biochemistry 4: 588 595, 1965

5) StaAb, H. A. \& W. Benz: Synthese und Eigenschaften von N-Carbonsäureamiden der Azole. Eine neue Isocyanat-Synthese. Ann. Chem. 648: 72 82, 1961 